\title{
Home-Based Learning (HBL) Teacher Readiness Scale: Instrument Development and Demographic Analysis
}

\author{
Azlin Norhaini Mansor, Nur Hidayah Zabarani, Khairul Azhar Jamaludin *, Mohamed Yusoff Mohd Nor, \\ Bity Salwana Alias and Ahmad Zamri Mansor
}

check for updates

Citation: Mansor, A.N.; Zabarani, N.H.; Jamaludin, K.A.; Mohd Nor, M.Y.; Alias, B.S.; Mansor, A.Z. Home-Based Learning (HBL) Teacher Readiness Scale: Instrument Development and Demographic Analysis. Sustainability 2021, 13, 2228. https://doi.org/10.3390/su13042228

Academic Editor: Ebba Ossiannilsson Received: 17 January 2021

Accepted: 14 February 2021

Published: 19 February 2021

Publisher's Note: MDPI stays neutral with regard to jurisdictional claims in published maps and institutional affiliations.

Copyright: (c) 2021 by the authors. Licensee MDPI, Basel, Switzerland. This article is an open access article distributed under the terms and conditions of the Creative Commons Attribution (CC BY) license (https:// creativecommons.org/licenses/by/ $4.0 /)$.
Faculty of Education, Universiti Kebangsaan Malaysia, Bangi 43600, Selangor, Malaysia; azlinmansor@ukm.edu.my (A.N.M.); nhzabarani@yes.my (N.H.Z.); yusoff1963@ukm.edu.my (M.Y.M.N.); bity@ukm.edu.my (B.S.A.); azamri@ukm.edu.my (A.Z.M.)

* Correspondence: khairuljamaludin@ukm.edu.my

\begin{abstract}
The unprecedented disruption in education due to the COVID-19 pandemic has forced teachers worldwide to adapt to online teaching and the immediate implementation of home-based learning (HBL). However, little is known regarding teacher readiness for HBL. Thus, there is a pressing need to develop an instrument to measure teachers' readiness for online teaching, which can provide feedback to guide policymakers and school leaders in planning strategic interventions and support for implementing HBL. This study aimed to refine and validate the HBL Teacher Readiness Scale and to ascertain the view of secondary school teachers on aspects of their readiness to implement HBL. A total of 931 from a population of 3826 secondary school teachers were selected using random sampling, from the state of Selangor, Malaysia. The validity and reliability of the HBL Teacher Readiness instrument were tested using exploratory factor analysis and reliability analysis. As a result of the analysis, the scale remained at 26 items across four factors, namely efficacy in technology, attitude, perceived behaviour control, and subjective norms. The Cronbach Alpha coefficient for the entire scale was 0.94. Demographic analysis revealed that, overall, the in-service teachers' level of readiness was at a high level across all dimensions, although the highest was in attitude and the lowest was in subjective norms. Based on this initial sample, the HBL Teacher Readiness Scale was shown to be a suitable instrument to measure teacher readiness for change in the context of the implementation of HBL, although further testing should be conducted on more diverse groups.
\end{abstract}

Keywords: COVID-19; emergency remote education; home-based learning; learning disruption; pandemic; teacher readiness

\section{Introduction}

Numerous learning disruptions have occurred across the globe over the past few decades and have profoundly altered almost all aspects of education [1,2]. From natural disasters to the recent unprecedented pandemic, millions have been affected [3]. According to a report from UNESCO (2020), the COVID-19 pandemic has entailed the largest disruption to the education system in history, affecting $94 \%$ of the world's student population in more than 190 countries. Consequently, it is essential for school systems around the world to quickly pivot to remote teaching and learning or home-based learning (HBL), resulting in significant changes to conventional instructional practices, which must transition from traditional face-to-face learning to learning from home using a mix of technologies [2,4-9].

The implementation of emergency remote education [10] is not new. It was first applied in the 19th century and has undergone much technological improvement [10-13]. Prior to COVID-19, remote teaching has been widely used in higher education [10,14-16]. Nevertheless, during the pandemic, this form of learning has become indispensable [17,18]. Large-scale, national efforts to utilize technology in support of remote teaching during the COVID-19 pandemic are emerging and evolving quickly [19]. The rapid evolution of Information Communication and Technology (ICT) explains why the integration of 
technology in education continues to receive special attention, particularly in the wake of the COVID-19 pandemic.

Remote teaching with a mix of technologies provides immediate solutions for most schools to ensure continuity in learning when adapting to a HBL system [3]. HBL implementation varies based on countries' policies and implementation $[1,16,20,21]$. Despite differences in implementation, the immediate measures taken by governments around the world have reflected common goals - not only to curb the spread of the disease but also to provide uninterrupted learning [2,22] and reduce inequality of access to education [1]. In a developed country like Finland, instruction and guidance for students have been implemented by distance learning, digital learning environments, and, when necessary, independent learning [9]. The Chinese Ministry of Education has launched an initiative to provide flexible online learning to hundreds of millions of students from their homes [23]. Meanwhile, in developing countries like Uganda, learning technologies such as print material, radio, television, video, etc. appear to enable learning opportunities, overcoming problems of geographical access and the rigidities of conventional education [21].

Malaysia is no exception to the recent calamity, with a total of 4.8 million students and nearly 5 hundred thousand teachers affected by school closures [24]. As in most countries, the Malaysian government issued a movement control order (MCO) in March 2020 to curb the spread of the pandemic [6] and adhere to the World Health Organization's [25] standard of physical and social distancing during the outbreak. The directive from the government to close down all learning institutions was welcomed by parents and other stakeholders of education as a good measure to prevent students from contracting the virus.

In this study, we refer to HBL as one of the remote teaching strategies developed in response to the sudden interruption caused by unexpected school closures. It is also referred to as distance learning by UNESCO [3] or remote teaching [10,14,26,27]. In Malaysia, a similar term (HBL) has been used to describe remote teaching [28]. A general guideline for conducting HBL during the pandemic has been provided by the Ministry of Education to ensure that learning and teaching take place during period of learning disruption [29]. The guidelines also provide alternative methods for teachers to carry out lessons in four modes, namely online, offline, mixed (a combination of online and offline), and off-site. This initiative is in line with UNESCO's [1] recommendations and ensures that distance learning programs aim for inclusivity, blend appropriate approaches, limit the number of applications and platforms used, develop distance learning rules, and actively monitor students' learning.

Although school closure was found to have successfully decreased the number of infected students at the peak of infection [30], as documented during the H1N1 and SARS outbreaks [31,32], certain countries like Malaysia have never experienced such extensive learning disruption. Thus, the ad hoc implementation of home-based learning has certainly met with some challenges of its own, especially among teachers, who must spearhead the implementation [9,33-35].

During this critical transition phase, teachers' readiness for executing HBL should not be overlooked as they are the front-line workers in the implementation $[3,5,7,24]$. As the most critical intellectual resources of any schools, teachers have faced various financial, physical, and mental struggles due to COVID-19 [35] and have been tasked with the huge responsibility of implementing new teaching practices in ways that promote student learning while maximizing student safety [3]. Consequently, teachers also face significant challenges in adapting to online teaching, maintaining adequate communication with students, and supporting students' learning and development [4]. Thus, a better understanding of the readiness of teachers as key players in the context of current change is the key to making the implementation more successful and sustainable [36,37]. When teachers are not ready for change, they may have a higher risk of negative attitudes and resistance [37], which will limit their own engagement and deprive their students of long-term positive results [38]. 
Although past researchers have paid attention to teachers' readiness for change [39-41] and distance education [13,42-46], only a few studies have discussed teachers' readiness for distance learning, especially in the context of the pandemic $[9,29,34,47]$ or in terms of coping with technology [47]. In discussing teachers' readiness to carry out home-based learning, it is essential to look at their technological readiness as it contributes to the effectiveness of distance learning strategies, alongside content readiness, pedagogical readiness, home-based support readiness, and monitoring and evaluation readiness [1,9]. Having said that, little is known regarding teachers' readiness to transition to emergency full-scale home-based learning with the integration of technology. Thus, there is a pressing need to develop an instrument to measure teachers' readiness for facing unprecedented crisis while meeting the demands of 21st-century teaching and learning.

Against this background, the purpose of this study is to refine and adjust a scale that might be employed to measure the extent of teachers' readiness to implement change during a crisis. To appropriately categorize teachers' readiness in implementing HBL in the context of a pandemic and to construct a HBL Teacher Readiness Scale, four aspects of teacher readiness have been identified, namely ICT self-efficacy, attitude, perceived behavioural control, and subjective norms. These four dimensions were adapted based on the Theory of Planned Behaviour [48] and social cognitive theory [49]. Thus, this paper's central objectives are:

a. To refine, adjust, and validate the HBL Teacher Readiness Scale based on a data sample of Gombak District Education Selangor's in-service teachers.

b. To ascertain the views of these in-service teachers on aspects of teachers' readiness for the implementation of HBL, including ICT efficacy, attitude, perceived behaviour control, and subjective norms.

\subsection{Teacher Readiness for Change}

Change is inevitable in the education system as a result of research, leadership, and policy. It is dynamic, exponential, and complex, yet it is also necessary to keep the existing management functioning $[37,50]$. As teachers are central to educational change and change is inevitable for any organisation that wants to move forward, they need to be prepared to manage any changes that come their way [51].

The literature on readiness for change is therefore relevant for understanding teachers' feelings and reactions in this unique setting. Readiness can be understood as "the cognitive precursor to the behaviors of either resistance to, or support for, a change effort" (p. 681) [52]. Originating in organizational studies, change readiness is defined as employees' beliefs regarding the appropriateness of, support for, and value of a change (p. 291) [53]. Assessing whether recipients are ready for the targeted change is crucial to ensure successful and effective implementation and sustainable change outcomes. Accordingly, teacher readiness for change, i.e., their understanding, confidence, positive attitude, and motivation towards implementing HBL, is an important factor influencing the successful implementation of system-wide change [54,55].

\subsection{Teacher Readiness for Implementing Home-Based Learning}

The implementation of HBL due to the pandemic has been perceived as an unstoppable change that teachers must adapt to [9] and that has further transformed the landscape of teaching and learning. It is undeniable that technology (i.e., online learning) appears to be the most feasible and appropriate form of distance learning, especially during a pandemic [18]. Even prior to the outbreak of COVID-19, ICT integration has been a highlight of the 21st-century teaching and learning process, as clearly stated in the Malaysian Education Blueprint 2013-2025. For instance, the use of mobile applications, namely WhatsApp, is found to be motivating as it encourages collaborative and active learning [56]. Nevertheless, this large-scale change that is being implemented abruptly is most likely to meet with strong resistance and weak readiness [57]. 
Over the years, many studies have been conducted to measure teacher technological readiness and readiness for distance education. Malaysian teachers' technological readiness for using common smartphone applications for teaching and learning was rated low to average [58,59]. However, in recent years, teacher technological readiness has shown notable improvement. A study conducted by Ventayen [46] on the readiness of teachers to adapt to online teaching showed that, despite limited experience in distance education and a lack of the requisite technical and time management skills, teachers were still able to cope with the trends in distance learning. Moreover, good readiness and satisfaction levels were also found among prospective teachers in other countries, such as Turkey and Thailand, in terms of web-based education [42,45]. Furthermore, in a study on the response of 205 online faculty members of higher institutions in the United States in terms of readiness, attitude, and ability to teach online, and in terms of course design, course communication, time management, and technical aspects, most scored highly [44]. Factors such as training, attitude, technical competence, time constraints, pedagogy, and methodology were among the major elements of adaptation to distance learning [13].

\subsection{A Model of Teacher Readiness for Home-Based Learning}

The four dimensions presented in this model are based on two theories. The first is the Theory of Planned Behaviour (TPB) proposed by Icek Ajzen [48]. TPB posits that individual behaviour is driven by behavioural intentions, a function of three determinants: an individual's attitude toward behaviour, subjective norms, and perceived behavioural control [48]. TPB has been applied in various contexts such as technology, healthcare, and politics, and explains that one's behaviour can be predicted based on his/her intention to engage with conduct [60-63]. The second theory used in this study is social cognitive theory $[64,65]$, which puts forward the concept of self-efficacy. This theory is pivotal in explaining the motivation or desire to perform a task. The four dimensions proposed in this paper are discussed in the following subsections.

\subsection{Attitude}

Attitude refers to the degree to which a person has a favourable or unfavourable feeling about performing a particular behaviour. Previous studies have found that attitude is a strong predictor of intention [48,63]. Back in the 1980s, teachers' attitudes contributed to the successful use of computers in classrooms [66]. Prior studies have also stated that attitude, knowledge, and skill in using computers contribute largely to teachers' initial acceptance of computer technology and their future behaviour regarding computer usage $[67,68]$.

Several studies conducted on Malaysian teachers' attitudes found that many teachers have a positive attitude towards the use of ICT in teaching various subjects, including core and elective subjects [69-71]. Furthermore, a study conducted in Saudi Arabia on attitudes towards e-learning among EFL teachers revealed that level of computer literacy has a positive influence on attitudes toward e-learning [72].

While most studies across the region have highlighted teachers' positive attitude towards the use of ICT in teaching, findings on Malaysian teachers' attitude towards change appear to differ [73]. Hassan et al. [73] found that teachers' attitudes towards change in the aspects of cognitive, affective, and behaviour were at an average level. To rectify this situation, researchers collectively proposed that the school head should take the lead in ensuring that teachers understand the importance of change [73,74].

\subsection{Perceived Behavioural Control}

Perceived behavioural control refers to individuals' perceptions of their ability to perform a particular behaviour [75], which can be discussed in two aspects, namely perceived ease of use and perceived usefulness [76]. These two variables are used in Davis' [62] Technology Acceptance Model (TAM) to provide an explanation of the determinants of technology acceptance. Perceived ease of use refers to the degree to which the prospective 
user expected the target system to be free of effort. Meanwhile, perceived usefulness is defined as the prospective user's subjective feeling that using a specific application system would increase his or her job performance within an organisational context. In previous studies, these two variables were found to have a significant and direct positive effect on users' intention to use an e-learning system [15,77].

\subsection{Subjective Norms}

A subjective norm is determined by accessible normative beliefs that account for the expectations of other people as an important determinant in behavioural intention [48]. These normative beliefs can be decomposed into multiple referent groups because each group may have different views [63]. For example, a school head may have a positive attitude toward a particular system, whereas teachers or peers may be opposed to the system. Normative beliefs are usually measured when a new system is introduced or tested, such as the implementation of HBL replacing face-to-face teaching. A subjective norm pertains to a person's perception of the social environment surrounding the behaviour [78]. In other words, others' opinions are significant in shaping an individual's intention to use new technologies, because individuals are dependent on context [79].

Cheon et al. [80], in their study on college students' adoption of mobile learning, found that a significant relationship exists between subjective norms and intentions. Nonetheless, the effect was somewhat lower. This finding is consistent with what Shiue [81] found in that the subjective environment weakly influenced the actual use of technology. A study conducted on factors affecting trainee teachers' intention to use technology in Bahrain has also found that subjective norms and attitude towards technology use were not significantly associated with the behavioural intention to use technology [82]. Yuen and Ma [15], in exploring teacher acceptance of e-learning technology, emphasized how school heads and principals can model technology themselves to encourage teachers to adapt to their behaviour.

\subsection{ICT Self-Efficacy}

Developed from social cognitive theory, self-efficacy refers to individuals' beliefs about their ability and motivation to perform specific tasks $[49,83]$. Not only is it an essential factor impacting readiness to manage change [52], teacher ICT self-efficacy is crucial in terms of how they develop beliefs about their abilities to integrate ICT when implementing HBL.

Studies by Al-Furaydi [72] and Hung et al. [84] found that teachers with computers and access to the Internet were likely to integrate e-learning in their teaching. Meanwhile, students with high self-efficacy performed better in online learning tasks. Furthermore, Sri Istiyowati and Prati [85] found that higher levels of self-efficacy with respect to computers led to higher levels of behavioural intent and use of information technology. From the abovementioned studies, we can reasonably assume that ICT self-efficacy among teachers implementing HBL is an essential element that boosts teacher readiness to carry out muchneeded change.

\section{Method}

\subsection{Research Design}

The study was carried out in two stages involving instrument development and data collection. A nonexperimental design, namely a survey design, was adopted in this work because a "numeric description of trends, attitudes, or opinions of a population can be obtained by studying a sample of that population" (p. 23) [86]. The study population was intended to include in-service teachers from Gombak District Education in Selangor. However, given that this work only aims to gather data to validate the applicability of the developed instrument for the main study, data were collected from 931 in-service teachers.

For studies that involve factor analysis, Hair et al. [87] suggested that an appropriate sample size should be used to produce reliable estimates. Gorsuch [88] and Kline [89] 
recommended at least five participants per construct and around 100 individuals per data analysis. No sample should have fewer than 100 individuals, even when the number of variables is under 20 [90].

\subsection{Sample}

In this pilot test, all respondents were secondary school, in-service teachers teaching at Gombak District Education in Selangor. After getting approval from the Educational Planning and Research Division (EPRD), Ministry of Education, Malaysia, the questionnaire's link was distributed via WhatsApp and Telegram. A total of 931 from a population of 3826 secondary school teachers in Gombak District Education in Selangor [91] responded to the questionnaire. The number of participants is representative of the population as it exceeded the minimum sampling size $(S=351, N=4000)$ suggested by Krejcie and Morgan [92]. In the questionnaire, all participants were instructed to answer the questionnaire based on their understanding, while simultaneously relating the meaning of each element to their experience.

Of the respondents, $153(16.4 \%)$ were male and $778(83.6 \%)$ were female. The minimum age of the respondents was 24 and the maximum age was 59 . The majority $(n=480,51.6 \%$ ) of them were between 36-49 years old, 276 respondents $(29.6 \%)$ were between 46 to 59 years old and only 173 respondents (18.8\%) were between 24 to 35 years old.

On the other hand, 336 respondents (36.1\%) had been teaching for more than 21 years; 240 respondents $(25.8 \%)$ had 11 to 15 years of teaching experience; 145 respondents (15.6\%) had six to ten years of teaching experience; $117(12.6 \%)$ respondents had 16 to 20 years of teaching experience; and only 93 (10\%) respondents had one to five years of teaching experience. All respondents had been directly affected by the implementation of HBL during the MCO. However, they did not face any difficulties with internet connection.

\subsection{Instrument Development}

A questionnaire survey was developed drawing from extant research on readiness for change, the Theory of Planned Behaviour [48], and Bandura's social cognitive theory [49,83]. Following Creswell and Clark [93], questionnaire development procedures included the following:

The instrument was divided into two parts. Part A consisted of nine items aimed at obtaining background information on respondents. Subsequently, Part B was a questionnaire to evaluate and identify teachers' readiness for the implementation of HBL. Part B consisted of 26 items. The instrument consisted of four constructs, namely establishing ICT efficacy, perceived behaviour control, subjective norms, and attitude. The questionnaire was constructed using a five-point Likert scale ranging from 1 (strongly disagree) to 5 (strongly agree). Respondents had to reflect on their current situation during the pandemic.

The process of constructing the HBL Teacher Readiness scale involved three stages, the first of which was the development of items in each aspect. The second was to validate each aspect, and the third was to conduct research followed by data analysis. In developing the item, the team performed a thorough literature review to determine the definition of each aspect, mainly focusing on teacher readiness to change and teachers' acceptance of technology. For the validation, we consulted three experts to determine the validity of the HBL Teacher Readiness Scale. The experts were three senior lecturers in educational leadership from University Kebangsaan Malaysia (UKM). Experts were consulted individually, and based on their feedback, items were refined to ensure they measured each factor precisely. A few items were reduced to prevent redundancies and survey fatigue among respondents.

\subsection{Data Analysis}

The validated questionnaire was completed by 931 respondents. In answering the research question, reliability testing, exploratory factor analysis (EFA), and Cronbach's Alpha testing were carried out using Statistical Package for Social Sciences (SPSS) software 
version 23.0. Data analysis was conducted in two steps. The first step considered considerable data screening-related issues, such as handling missing data, multicollinearity, and the identification of outliers and normality. For the examination of normality, the skewness and kurtosis values of each item, ranging from -1.96 to +1.96 at a 0.05 significance level [94], were used. In terms of multicollinearity, the correlation amongst factors should be less than 0.90 [95]. In the second step, Cronbach's alpha and descriptive statistics were carried out. Cronbach's alpha was computed to determine the reliability of the instrument (total and subconstructs). Hair et al. [94] reported that alpha values of 0.60 to 0.70 are satisfactory.

\section{Results}

This study needs to meet certain requirements to ensure that this instrument is acceptable and applicable. Among the requirements needing to be met are the suitability of the item measuring the construct and the reliability of the item used. EFA and Cronbach's Alpha reliability analyses were used to measure the suitability of the constructs and items used.

\subsection{Exploratory Factor Analysis (EFA)}

EFA was performed to obtain constructs and items that could both measure and fit this study. In order to analyse the valid items for each component, a Kaiser-Meyer-Olkin (KMO) test and Bartlett's test of sphericity have been carried out. Table 1 shows that the $\mathrm{KMO}$ test resulted in a value of 0.939 . This value exceeded the recommended value of $0.6[96,97]$, indicating that the sample was adequate to test the factor analysis.

Table 1. Kaiser-Meyer-Olkin (KMO) and Bartlett's test.

\begin{tabular}{cc}
\hline Test & Value \\
\hline Kaiser-Meyer-Olkin Measure of Sampling Adequacy. & 0.939 \\
Bartlett's Test of Sphericity & \\
Approx. Chi-Square & $27,734.518$ \\
df & 325 \\
Sig. & $<0.001$ \\
\hline
\end{tabular}

EFA of the aspects of teacher readiness in implementing HBL began with 26 items. In the process of identifying factors, two methods have been used to determine the number of factors that are appropriate for the questionnaire constructed. First, referring to Kaiser's criteria, we found that researchers should choose factors with Eigenvalues greater than 1.0, which indicated that the items in the instrument contained more than one factor. The Oblimin rotation process was then performed to discard items with a coefficient below 0.3 . The total number of items with a coefficient value of over 0.3 was 26 .

The analysis showed that 26 items were collected under four factors with Eigenvalues greater than 1 . Next, the researchers referred to the second approach taken (principal component analysis (PCA) with Oblimin with Kaiser normalisation) and the appropriateness of the items selected to characterise the instrument's development. The solution of the Oblimin with Kaiser normalisation method revealed the presence of a simple structure (see Table 2), with all four components demonstrating a number of strong factor loadings. The test results demonstrated that there are four points before the line straightens. This shows that there are four components with Eigenvalues exceeding the corresponding criterion values for a randomly generated data matrix of the same size ( 26 items by 931 respondents). The decision was made to retain the first four components for further analysis. 
Table 2. Principal component analysis (PCA) of the rotated component matrix.

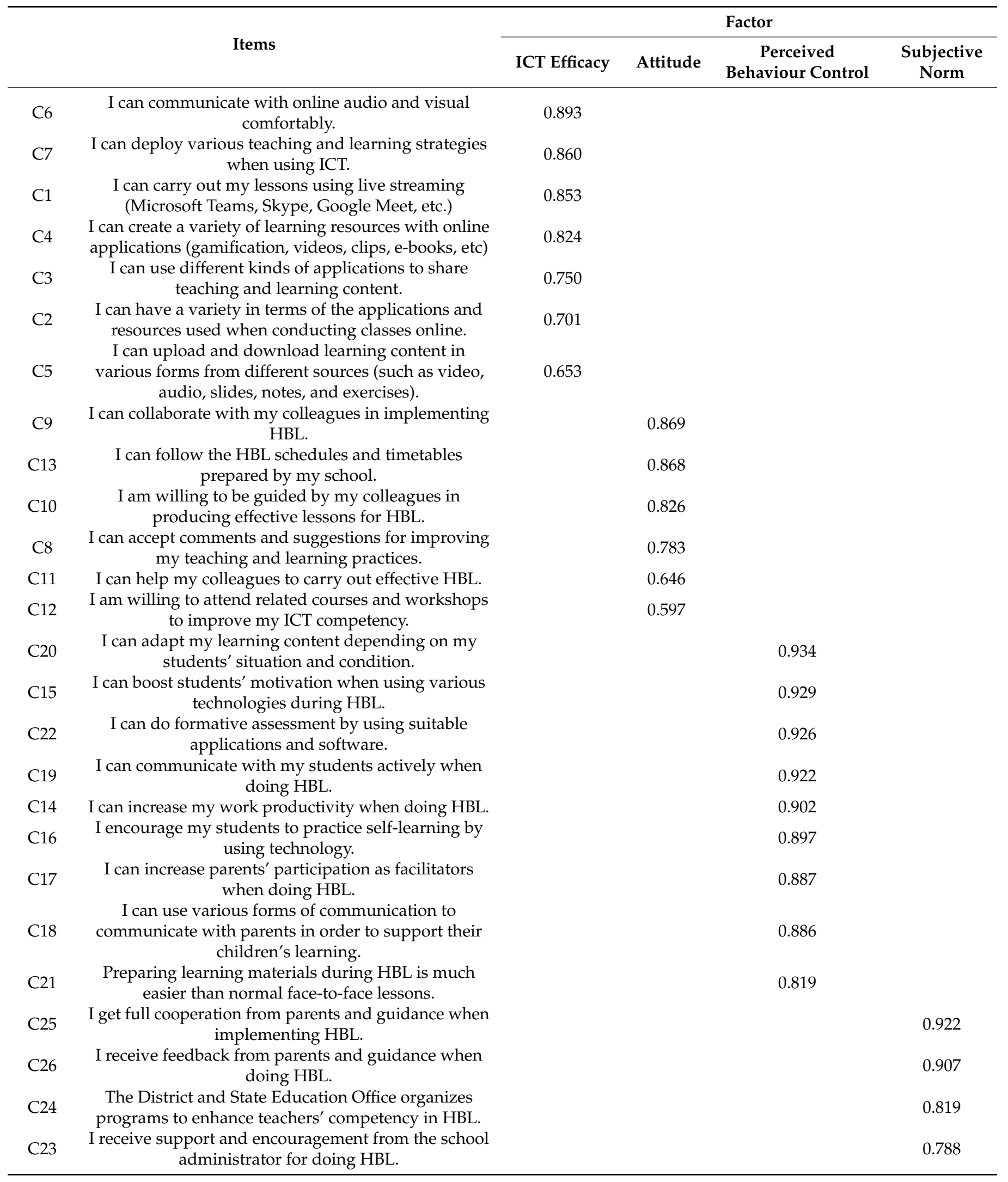




\subsection{Rotation Method: Oblimin with Kaiser Normalisation}

Table 2 reveals that all loading factor values for each item reach acceptable values of above 0.30 . Item loading factors greater than 0.30 are considered to have good internal consistency [94,98]. Through the Oblimin rotation process, the rotated tablespace matrix demonstrates that the questionnaire items are four-dimensional (containing four factors). Four factors predicted $78.57 \%$, with factor 1 with 42.58 variance, factor 2 with $22.83 \%$ variance, factor 3 with $8.09 \%$ variance, and factor 4 with $5.08 \%$ variance. The values in the rotated component matrix show that factor 1 contains seven items (C1-C7), factor 2 contains six items (C8-C13), factor 3 contains nine items (C14-C22), and factor 4 contains four items (C23-C26). Table 3 illustrates the result of the Oblimin rotation process. Thus, a four-factor solution confirms the four dimensions of teacher readiness for the HBL model, as proposed by Ajzen [48] and Compeau et al. [64,65].

Table 3. Results of the Oblimin rotation process.

\begin{tabular}{ccc}
\hline Factor & Number of Items & \% of Variance \\
\hline Self-efficacy towards ICT & $7(\mathrm{C} 1-\mathrm{C} 7)$ & 42.58 \\
Attitudes & $6(\mathrm{C} 8-\mathrm{C} 13)$ & 22.83 \\
Perceived behavioural control & $9(\mathrm{C} 14-\mathrm{C} 22)$ & 8.09 \\
Subjective norms & $4(\mathrm{C} 23-\mathrm{C} 26)$ & 5.08 \\
\hline
\end{tabular}

By examining each factor item according to the model and literature framework, items under factor 1 can be placed under the aspect of self-efficacy towards ICT, factor 2 under the aspect of attitudes, factor 3 under perceived behavioural control, and factor 4 under subjective norms. Items loaded from each of the four components have strong, clear, and conceptual links.

\subsection{Reliability Analysis}

The Cronbach's alpha reliability value for the entire scale was 0.83 . The Cronbach alpha coefficient for each of the four components was calculated as $0.84,0.84,0.87$, and 0.77 , respectively. These values indicate that the resulting factor is exceptionally strong, and the reliability value is very high.

\subsection{Multicollinearity Analysis}

Multicollinearity problems occur when the correlation value between the variables is too high by 0.8 [87]. In this study, the correlation values between the variables varied within a range of 0.119 to 0.708 ; this means that the correlation between variables is less than 0.9 , and multicollinearity problems do not occur.

\subsection{Level of Teacher Readiness for Implementing HBL}

Subsequently, an analysis was conducted to assess teachers' level of readiness for implementing HBL based on the four factors identified in this study.

Table 4 illustrates the results of the mean score analysis of the level of teacher readiness for implementing HBL by construct.

Table 4. The mean score of the level of teacher readiness for implementing HBL.

\begin{tabular}{cccc}
\hline Construct & Mean Score & Standard Deviation & Level \\
\hline ICT efficacy & 3.91 & 0.609 & High \\
Attitude & 4.08 & 0.577 & High \\
Perceived Behavioural Control & 3.78 & 0.589 & High \\
Subjective norms & 3.70 & 0.666 & High \\
Total & 3.87 & 0.610 & High \\
\hline
\end{tabular}


The interpretation of mean scores is based on Hamzah, Juraime and Mansor's [99] suggestion, as illustrated in Table 5 . The overall mean score was $\mathrm{M}=3.87$ (S.D. $=0.610$ ).

Table 5. Interpretation of the mean score.

\begin{tabular}{cc}
\hline Mean Score & Interpretation \\
\hline $1.00-1.80$ & Very low \\
$1.81-2.60$ & Low \\
$2.61-3.20$ & Medium \\
$3.21-4.20$ & High \\
$4.21-5.00$ & Very high \\
\hline
\end{tabular}

This indicates that the overall level of teacher readiness towards the implementation of HBL was high. In addition, attitude was the dimension that had the highest mean score $(\mathrm{M}=4.08$, S.D. $=0.577)$, and subjective norms was the dimension with the lowest mean score $(\mathrm{M}=3.70, \mathrm{SD}=0.666)$.

\section{Discussion}

The main purpose of this study was to refine and validate the items in the HBL Teacher Readiness Scale. Thus, an instrument with 26 items was generated, with several items being dropped during validation by experts from the education field. These items were deleted because they were redundant in meaning and to avoid survey fatigue among respondents. This instrument is valid and reliable for use in future studies involving teacher readiness for implementing HBL. The four elements of teacher readiness for implementing HBL are ICT efficacy, attitude, perceived behavioural control, and subjective norms.

The developed instrument is based on the Theory of Planned Behaviour [48] and Bandura's Social Cognitive theory $[49,83]$. In facing abrupt learning disruption, teachers' readiness to implement full-scale HBL can be explained through four components. In fact, all components possess an acceptable Cronbach alpha value. The overall reliability of the instrument was 0.83 , and the Cronbach's alpha value for each factor showed a consistent internal consistency value of 0.77 to 0.87 . The reliability values were both very good and sufficiently high.

In addition to the initial validation of the HBL Teacher Readiness Scale and the identification of its various components, this study also examined the level of teacher readiness for implementing HBL. The findings showed that teachers' readiness to implement HBL was at a high level for all factors, which indicates that teachers had strong readiness for implementing home-based learning during a crisis. This finding differs from that of Rafferty and Simon [57], who suggested that large-scale change is likely to meet with strong resistance and weak readiness.

Furthermore, attitude was found to have the highest score compared with the other three dimensions. This finding indicates that teachers' attitude contributes to their readiness, which is crucial for implementing change [37]. This contradicts Hassan et al. [73], who revealed teachers' attitude towards change to be at a moderate level. Nevertheless, it can be said that teachers in the current study would probably have a different set of attitudes towards embracing change due to the support they get from their leaders. Leaders' support has been proven in many studies to be essential in getting workers to embrace change [100].

The findings also show that the subjective norm dimension yields the lowest mean scores, which implies that most respondents were most likely not affected by their surroundings, particularly in terms of their working environment. Teachers might be feeling less pressure since they are working from home and have less contact with their colleagues or principal. However, as mentioned by Yuen and Ma [15], in making sure teachers carry out their duties effectively, the school head should play a role in not just monitoring but also modelling the desired change to serve as an example to their subordinates.

The results of this study can serve as a guide for research into teacher readiness to adapt to change, particularly during learning disruption. The results can also enhance the 
corpus of knowledge (theory) and serve as an input for Ministry of Education Malaysia to improve the implementation of HBL policies, especially in terms of leaders' roles in supporting teachers to implement the required change. The HBL Teacher Readiness Scale enables the evaluation of teachers' beliefs, abilities, willingness and motivation to conduct HBL. This scale can be adapted for respondents from various backgrounds to match researchers' needs and creativity. However, attention should be paid to the construction and validation processes, as the current scale is designed to measure teacher readiness in implementing HBL in the current context of learning disruption.

\section{Limitations}

The results of this study represent the perspectives of in-service teachers teaching in an urban area and may not represent the voice of all teachers in Malaysia. Further research into teacher readiness for learning disruption should be conducted with a broader and more diverse range of respondents.

\section{Conclusions}

The results of this study confirm the validity and reliability of the HBL Teacher Readiness Scale for measuring teachers' readiness for implementing HBL during learning disruption. Four elements have been identified in this instrument, and the 26-item version is deemed appropriate to measure teachers' readiness for change based on the conceptual and practical aspects of change. The findings also confirmed that teachers' readiness for implementing HBL was high, which is crucial in the unfreezing stage and is now moving towards the final stage of the change process, namely freezing the desired change. The study concludes that the HBL Teacher Readiness Scale is a useful instrument through which to identify the level as well as the stage of teacher readiness to change and to use as feedback to guide school leaders when giving much-needed support for implementing HBL. Both the findings and the instrument can inform policymakers, help monitor the status of HBL implementation and plan strategic interventions to achieve desired outcomes within the Malaysian education system.

Author Contributions: Conceptualization, A.N.M. and N.H.Z.; Writing, review and editing, A.N.M., N.H.Z., K.A.J. and A.Z.M.; Data Collection, N.H.Z., K.A.J. and B.S.A.; Data Analysis, N.H.Z. and M.Y.M.N. All authors have read and agreed to the published version of the manuscript.

Funding: Faculty of Education, Universiti Kebangsaan Malaysia Research Grant GG-2020-020.

Institutional Review Board Statement: The study was conducted according to the guidelines given by the Educational Planning and Research Division, Ministry of Education Malaysia.

Informed Consent Statement: Informed consent was obtained from all subjects involved in the study.

Data Availability Statement: The data presented in this study are available on request from the corresponding author. The data are not publicly available due to data restriction policy by the grant provider.

Conflicts of Interest: The authors declare no conflict of interest.

\section{References}

1. UNESCO. Distance Learning Strategies in Response to COVID-19 School Closures; UNESCO Education Sector's Issue Notes; UNESCO: Paris, France, April 2020; pp. 1-8. Available online: https://unesdoc.unesco.org/ark:/48223/pf0000373305?posInSet=2\& ;queryId=N-8ea77989-29de-4ff3-997c-eaddc678be5b (accessed on 17 September 2020).

2. Alam, A.; Tiwari, P. Putting the 'Learning' Back in Remote Learning (June). Available online: https://www.unicef.org/ globalinsight/sites/unicef.org.globalinsight/files/2020-06/UNICEF-Global-Insight-remote-learning-issue-brief-2020.pdf (accessed on 24 September 2020).

3. UNESCO. Supporting Teachers to Maintain Continuity of Learning During School Closures. In Proceedings of the UNESCO COVID-19 Education Response Webinar; UNESCO: Paris, France, 27 March 2020; pp. 1-10. Available online: www.unesco.org (accessed on 24 September 2020).

4. Sokal, L.J.; Trudel, L.G.E.; Babb, J.C. Supporting teachers in times of change: The job demands-resources model and teacher burnout during the COVID-19 pandemic. Int. J. Contemp. Educ. 2020, 3, 67. [CrossRef] 
5. World Bank. Guidance Note on Education Systems' Response to COVID19. Available online: https://www.cdc.gov / coronavirus / 2019-ncov/downloads/considerations-for-school-closure.pdf (accessed on 20 August 2020).

6. Kong, Q. Practical exploration of home study guidance for students during the COVID-19 pandemic: A case study of Hangzhou Liuxia elementary school in Zhejiang province, China. Sci. Insights Educ. Front. 2020, 5, 557-561. [CrossRef]

7. König, J.; Jäger-Biela, D.J.; Glutsch, N. Adapting to online teaching during COVID-19 school closure: Teacher education and teacher competence effects among early career teachers in Germany. Eur. J. Teach. Educ. 2020, 43, 608-622. [CrossRef]

8. Noman, M.; Awang Hashim, R.; Shaik Abdullah, S. Contextual leadership practices: The case of a successful school principal in Malaysia. Educ. Manag. Adm. Leadersh. 2018, 46, 474-490. [CrossRef]

9. Rasmitadila, R.; Aliyyah, R.R.; Rachmadtullah, R.; Samsudin, A.; Syaodih, E.; Nurtanto, M.; Tambunan, A.R.S. The perceptions of primary school teachers of online learning during the COVID-19 pandemic period: A case study in Indonesia. J. Ethn. Cult. Stud. 2020, 7, 90-109. [CrossRef]

10. Toquero, C.M. Emergency remote education experiment amid COVID-19 pandemic. Int. J. Educ. Res. Innov. 2020, 15, 162-176. [CrossRef]

11. King, F.B.; Young, M.F.; Drivere-Richmond, K.; Schrader, P.G. Defining distance learning and distance education. Assoc. Adv. Comput. Educ. J. 2001, 9, 1-14.

12. Morgan, H. Best practices for implementing remote learning during a pandemic. Clear. House A J. Educ. Strateg. Issues Ideas 2020, 93, 135-141. [CrossRef]

13. Phan, T.T.N.; Dang, L.T.T. Teacher readiness for online teaching: A critical review. Int. J. Open Distance E Learn. IJODeL 2017, 3 , 1-16. Available online: http:/ /ijodel.com/wp-content/uploads/2017/12/001_Phan_Dang.pdf (accessed on 15 June 2020).

14. Ferri, F.; Grifoni, P.; Guzzo, T. Online learning and emergency remote teaching: Opportunities and challenges in emergency situations. Societies 2020, 10, 86. [CrossRef]

15. Yuen, A.H.K.; Ma, W.W.K. Exploring teacher acceptance of e-learning technology. Asia Pac. J. Teach. Educ. 2008, 36, 229-243. [CrossRef]

16. Zhao, J.; Xiao, H.; Li, Y.; Wen, D.; Xu, P.; Fu, Y.; Piao, J.; Liu, J.; Cao, D.; Zhong, Z.; et al. Experience of massive distance online education for medical colleges and universities in China to counter the COVID-19 pandemic. Res. Sq. 2020, 1-13. [CrossRef]

17. Doghonadze, N.; Aliyev, A.; Halawachy, H.; Knodel, L.; Adedoyin, A.S. The degree of readiness to total distance learning in the face of COVID-19-Teachers' view (case of Azerbaijan, Georgia, Iraq, Nigeria, UK and Ukraine). J. Educ. Black Sea Reg. 2020, 5, 2-41. [CrossRef]

18. Kaur, G. Digital life: Boon or bane in teaching sector on COVID-19. Clio Annu. Interdiscip. J. Hist. 2020, 6, 416-427.

19. Ali, W. Online and remote learning in higher education institutes: A necessity in light of COVID-19 pandemic. High. Educ. Stud. 2020, 10, 16. [CrossRef]

20. Tauson, M.; Stannard, L. EdTech for Learning in Emergencies and Displaced Settings: A Rigorous Review and Narrative Synthesis. Available online: https:/ / resourcecentre.savethechildren.net/node/13238/pdf/edtech-learning.pdf (accessed on 20 September 2020).

21. Tumwesige, J. COVID-19 Educational Disruption and Response: Rethinking e-Learning in Uganda. Available online: https:/ / www.kas.de/en/web/uganda/single-title/-/content/covid-19-educational-disruption-and-response (accessed on 17 September 2020).

22. Leacock, C.J.; Warrican, S.J.; Warrican, S.J. Helping teachers to respond to COVID-19 in the Eastern Caribbean: Issues of readiness, equity and care Caribbean: Issues of readiness, equity and care. J. Educ. Teach. 2020, 46, 1-10. [CrossRef]

23. Huang, R.H.; Liu, D.J.; Tlili, A.; Yang, J.F.; Wang, H. Handbook on Facilitating Flexible Learning During Educational Disruption: The Chinese Experience in Maintaining Undisrupted Learning in COVID-19 Outbreak. Available online: https:/ /iite.unesco.org/wp-content/uploads/2020/03/Handbook-on-Facilitating-Flexible-Learning-in-COVID-19-OutbreakSLIBNU_V2.0_20200324.pdf (accessed on 30 August 2020).

24. UNICEF Malaysia. Covid-19: A child rights crisis. In UNICEF Malaysia's Special e-Newsletter on COVID-19 Impact E Response in Malaysia; United Nations Children's Fund Malaysia: Putrajaya, Malaysia, 2020; pp. 1-6. Available online: https://www.unicef. org/malaysia/media/1361/file/COVID_Newsletter_1.pdf (accessed on 28 July 2020).

25. World Health Organization. Coronavirus Disease (COVID-19) Advice for the Public. Available online: https://www.who.int/ emergencies/diseases/novel-coronavirus-2019/advice-for-public (accessed on 20 July 2020).

26. Talidong, K.J.B. Implementation of emergency remote teaching (ERT) among Philippine teachers in Xi'an, China. Asian J. Distance Educ. 2020, 15, 196-201. [CrossRef]

27. World Bank. Remote Learning, Distance Education and Online Learning during the COVID19 Pandemic: A Resource List by the World Bank's Edtech Team (English). Available online: http://documents.worldbank.org/curated/en/964121585254860581 /Remote-Learning-Distance-Educationand-Online-Learning-During-the-COVID19-Pandemic-A-Resource-List-by-the-WorldBanks-Edtech-Team (accessed on 10 February 2020).

28. Ministry of Education Malaysia. Manual Pengajaran dan Pembelajaran di Rumah [Home Based Teaching and Learning Manual]. Available online: https:/ / www.moe.gov.my/muat-turun/lain-lain/manual-pdp-di-rumah/3727-manual-pdpdr/file (accessed on 10 February 2020). 
29. Ministry of Education. Surat Siaran KPM Bil 3 Tahun 2020: Garis Panduan Pengajaran dan Pembelajaran (PdP) Semasa Perintah Kawalan Pergerakan Disebabkan Penularan Jangkitan COVID-19 [Ministry of Education Release Letter No. 3 of 2020: Guidelines for Teaching and Learning During the Movement Control Order due to Widespread of COVID-19]. Available online: https:/ / www.moe.gov.my/pekeliling/3361-surat-siaran-kpm-bilangan-3-tahun-2020-garis-panduan-pelaksanaanpengajaran-dan-pembelajaran-pdp-semasa-pkp-disebabkan-penularan-jangkitan-covid-19/file (accessed on 20 July 2020).

30. Owusu-Fordjour, C.; Koomson, C.K.; Hanson, D. The impact of COVID-19 on learning-the perspective of the Ghanaian student. Eur. J. Educ. Stud. 2020, 7, 88-101. [CrossRef]

31. Adnan, M. Online learning amid the COVID-19 pandemic: Students perspectives. J. Pedagog. Res. 2020, 2, 45-51. [CrossRef]

32. Cauchemez, S.; Van Kerkhove, M.D.; Archer, B.N.; Cetron, M.; Cowling, B.J.; Grove, P.; Oshitani, H. School closures during the 2009 Influenza pandemic: National and local experiences. BMC Infect. Dis. 2014, 14, 207. [CrossRef]

33. Kaden, U. Covid-19 school closure-related changes to the professional life of a K-12 teacher. Educ. Sci. 2020, 10, 165. [CrossRef]

34. Lapada, A.A.; Miguel, F.F.; Robledo, D.A.R.; Alam, Z.F. Teachers' COVID-19 awareness, distance learning education experiences and perceptions towards institutional readiness and challenges. Int. J. Learn. Teach. Educ. Res. 2020, 19, 127-144. [CrossRef]

35. Vu, C.T.; Hoang, A.D.; Than, V.Q.; Nguyen, M.T.; Dinh, V.H.; Le, Q.A.T.; Le, T.T.T.; Pham, H.H.; Nguyen, Y.C. Dataset of Vietnamese teachers' perspectives and perceived support during the COVID-19 pandemic. Data Brief 2020, 31, 105788. [CrossRef]

36. Du, X.; Chaaban, Y. Teachers' readiness for a statewide change to PjBL in primary education in Qatar. Interdiscip. J. Probl. Based Learn. 2020, 14, 1-14. [CrossRef]

37. Fullan, M. Change theory as a force for school improvement. In Intelligent Leadership; Studies in Educational Leadership; Berger, J.M., Webber, C.F., Klinck, P., Eds.; Springer: Dordrecht, The Netherlands, 2007; Volume 6. [CrossRef]

38. Moesby, E. Reflections on making a change towards Project Oriented and Problem-Based Learning (POPBL). World Trans. Eng. Technol. Educ. 2004, 3, 269-278.

39. Armenakis, A.A.; Fredenberger, W.B. Organizational change readiness practices of business turnaround change agents. Knowl. Process Manag. 1997, 4, 143-152. [CrossRef]

40. Bouckenooghe, D.; Devos, G.; Van den Broeck, H. Organizational change questionnaire-climate of change, processes, and readiness: Development of a new instrument. J. Psychol. Interdiscip. Appl. 2009, 143, 559-599. Available online: http://ovidsp. ovid.com/ovidweb.cgi?T=JS\&PAGE=reference\&D=emed9\&NEWS=N\&AN=19957876 (accessed on 15 April 2020).

41. Hung, M.L. Teacher readiness for online learning: Scale development and teacher perceptions. Comput. Educ. 2016, 94, 120-133. [CrossRef]

42. Akarawang, C.; Kidrakran, P.; Nuangchalerm, P. Enhancing ICT competency for teachers in the Thailand basic education system. Int. Educ. Stud. 2015, 8, 1-8. [CrossRef]

43. Fedina, N.V.; Burmykina, I.V.; Zvezda, L.M.; Pikalova, O.S.; Skudnev, D.M.; Voronin, I.V. Study of educators' and parents' readiness to implement distance learning technologies in preschool education in Russia. Eurasia J. Math. Sci. Technol. Educ. 2017, 13, 8415-8428. [CrossRef]

44. Martin, F.; Budhrani, K.; Wang, C. Examining faculty perception of their readiness to teach online. Online Learn. J. 2019, 23, 97-119. [CrossRef]

45. Ozturk, D.S.; Ozturk, F.; Ozen, R. The relationship between prospective teachers' readiness and satisfaction about web-based distance education. Turk. Online J. Distance Educ. 2018, 19, 147-162. [CrossRef]

46. Ventayen, R.J. Teachers' readiness in online teaching environment: A case of department of education teachers. J. Educ. Manag. Soc. Sci. 2018, 2, 94-106. Available online: www.psurj.org/jemss (accessed on 15 May 2020).

47. Sutherland-Smith, W. Weaving the literacy web: Changes in reading from page to screen. Read. Teach. 2002, 55, 662-669.

48. Ajzen, I. The theory of planned behavior. Organ. Behav. Hum. Decis. Process. 1991, 50, 179-211. [CrossRef]

49. Bandura, A. Social Foundations of Thought and Action; Prentice-Hall: Englewood Cliffs, NJ, USA, 1986.

50. Kotter, J.P. A Force for Change: How Leadership Differs from Management; Free Press: New York, NY, USA, 1990.

51. Datnow, A. The role of teachers in educational reform: A 20-year perspective. J. Educ. Chang. 2020, 21, 109-113. [CrossRef]

52. Armenakis, A.A.; Harris, S.G.; Mossholder, K.W. Creating readiness for organizational change. Hum. Relat. 1993, 46, 681-703. [CrossRef]

53. Armenakis, A.A.; Harris, S.G.; Feild, H.S. Making change permanent: A model for institutionalizing change interventions. In Research in Organizational Change and Development; Pasmore, W.A., Woodman, R.W., Eds.; JAI Press: New York, NY, USA, 1999; Volume 12, pp. 97-128.

54. Adelman, H.S.; Taylor, L. The School Leader's Guide to Student Learning Supports: New Directions for Addressing Barriers to Learning; Corwin Press: Thousand Oaks, CA, USA, 2006.

55. Bliss, C.M.; Wanless, S.B. Development and initial investigation of a self-report measure of teachers' readiness to implement. J. Educ. Chang. 2018, 19, 269-291. [CrossRef]

56. Husin, N.; Azmi, N.A.N.; Daud, M.M. Pembelajaran kolaboratif melalui aplikasi telefon pintar dalam pembelajaran nahu [Collaborative Learning Through Smartphone Applications in Grammar Learning]. e-Jurnal Penyelidikan Dan Inovasi 2017, 4, 43-63.

57. Rafferty, A.E.; Simons, R.H. An examination of the antecedents of readiness for fine-tuning and corporate transformation changes. J. Bus. Psychol. 2006, 20, 325-350. [CrossRef] 
58. Mohamed, N.; Hassan, H.; Abu Hassan, M.N.Z. Komunikasi ICT dalam pengajaran terhadap murid-murid pra sekolah: Satu tinjauan [ICT communication in teaching to pre-school pupils: An overview]. J. Penyelid. Tempawan 2014, 31, $171-187$.

59. Nawi, A.; Hamzah, M.I. Tahap penerimaan penggunaan telefon bimbit sebagai M-pembelajaran dalam pendidikan Islam [Level of acceptance of the use of mobile phones as M-learning in Islamic education]. J. Islamic Arab. Educ. 2013, 5, 1-10.

60. Barnard-Bark, L.; Burley, H.; Crooks, S.M. Explaining youth mentoring behavior using theory of planned behavior perspective. Int. J. Adolesc. Youth 2010, 15, 365-379. [CrossRef]

61. Conner, M.; Armitage, C.J. Extending the theory of planned behavior: A review and avenues for further research. J. Appl. Soc. Psychol. 1998, 28, 1429-1464. [CrossRef]

62. Davis, F.D. Perceived usefulness, perceived ease of use and user acceptance of information technology. MIS Q. 1989, 13, 319-339. [CrossRef]

63. Taylor, S.; Todd, P.A. Understanding information technology usage: A test of competing models. JSTOR 1995, 6, 144-176. [CrossRef]

64. Compeau, D.; Higgins, C.A. Computer self-efficacy: Development of a measure and initial test. MIS Q. 1995, 19, 189. [CrossRef]

65. Compeau, D.; Higgins, C.A.; Huff, S.L. Social cognitive theory and individual reactions to computing technology: A longitudinal study. MIS Q. 1995, 23, 145-158. [CrossRef]

66. Lawton, J.; Gerschner, V.T. A review of the literature on attitudes towards computers and computerized instruction. J. Res. Dev. Educ. 1982, 16, 50-55.

67. Koohang, A. A study of attitudes toward computers: Anxiety, confidence, liking and perception of usefulness. J. Res. Comput. Educ. 1989, 22, 137-150. [CrossRef]

68. Violato, C.; Mariniz, A.; Hunter, W. A confirmatory analysis of a four-factor model of attitudes toward computers: A study of pre-service teachers. J. Res. Comput. Educ. 1989, 21, 199-213. [CrossRef]

69. Halili, S.H.; Suguneswar, S. Penerimaan guru terhadap penggunaan teknologi maklumat dan komunikasi berasaskan Model Tam dalam pengajaran mata pelajaran Bahasa Tamil [Teachers' acceptance of the use of information and communication technology based on the TAM Model in the teaching of Tamil Subject]. J. Kurikulum Pengajaran Asia Pasifik 2016, 4, 31-41.

70. Nadarajan, M. Tahap Penggunaan Teknologi Maklumat Di Kalangan Guru-Guru Ekonomi: Satu Tinjauan [Level of Information Technology Application Among Economics Teachers: An Overview]. Master's Thesis, Universiti Kebangsaan Malaysia, Bangi Selangor, Malaysia, 2002.

71. Solah, S.M. Persepsi Terhadap Kesediaan Dan Tahap Penggunaan Teknologi Maklumat Dan Komunikasi (Tmk) Dalam Kalangan Guru Bahasa Melayu Di Sekolah Menengah Kebangsaan Bandar Dan Luar Bandar [Perception and Readiness Level of Information and Communication Technology (ICT) Application among Malay Language Teacher in Urban and Rural Schools]. Master's Thesis, Universiti Kebangsaan Malaysia, Bangi Selangor, Malaysia, 2006.

72. Al-Furaydi, A.A. Measuring E-learning readiness among EFL teachers in intermediate public schools in Saudi Arabia. Engl. Lang. Teach. 2013, 6, 110-121. [CrossRef]

73. Hassan, M.A.A.; Rabani, M.F.; Shukor, M.E.M.; Majid, M.M.A. Sikap guru terhadap perubahan dalam sekolah di Malaysia [Teacher attitudes toward change in schools in Malaysia]. Manag. Res. J. 2018, 7, 188-196. [CrossRef]

74. Tan, M.K.; Kareem, O.A.; Ghouri, A.M. Competency of school principals in managing change in Malaysian secondary schools: Teachers' perspective. Int. J. Acad. Res. Bus. Soc. Sci. 2019, 9, 285-304. [CrossRef]

75. Ajzen, I. Perceived behavioral control, self-efficacy, locus of control, and the theory of planned behavior. J. Appl. Soc. Psychol. 2002, 32, 665. [CrossRef]

76. Trafimow, D.; Sheeran, P.; Conner, M.; Finlay, K.A. Evidence that perceived behavioural control is a multidimensional construct: Perceived control and perceived difficulty. Br. J. Soc. Psychol. 2002, 41, 101-121. [CrossRef] [PubMed]

77. Venkatesh, V.; Morris, M.G.; Davis, G.B.; Davis, F.D. User acceptance of information technology: Toward a unified view. MIS Q. 2003, 27, 425-478. [CrossRef]

78. Venkatesh, V.; Davis, F.D. A theoretical extension of the technology acceptance model: Four longitudinal field studies. Manag. Sci. 2000, 46, 186-204. [CrossRef]

79. Shah, P.P. Who are employees' social referents? Using a network perspective to determine referent others. Acad. Manag. J. 1998, $41,249-268$.

80. Cheon, J.; Lee, S.; Crooks, S.M.; Song, J. An investigation of mobile learning readiness in higher education based on the theory of planned behavior. Comput. Educ. 2012, 59, 1054-1064. [CrossRef]

81. Shiue, Y. Investigating the sources of teachers' instructional technology use through the decomposed theory of planned behavior. J. Educ. Comput. Res. 2007, 36, 425-453. [CrossRef]

82. Eksail, F.A.A.; Afari, E. Factors affecting trainee teachers' intention to use technology: A structural equation modeling approach. Educ. Inf. Technol. 2020, 25, 2681-2697. [CrossRef]

83. Bandura, A. Self-Efficacy: The Exercise of Control; W.H. Freeman: New York, NY, USA, 1997.

84. Hung, M.L.; Chou, C.; Chen, C.H.; Own, Z.Y. Learner readiness for online learning: Scale development and student perceptions. Comput. Educ. 2010, 55, 1080-1090. [CrossRef]

85. Sri Istiyowati, L.; Prati, P. Mobile learning readiness in higher education based on the theory of planned behavior. Int. J. Recent Technol. Eng. 2019, 8, 831-836. 
86. Creswell, J.W. Educational Research: Planning, Conducting and Evaluating Quantitative and Qualitative Research, HLM, 4th ed.; Pearson: Boston, MA, USA, 2014.

87. Hair, J.F.J.; Anderson, R.E.; Tatham, R.L.; Black, W.C. Multivariate Data Analysis, HLM, 5th ed.; Prentice Hall: Upper Saddle River, NJ, USA, 1998.

88. Gorsuch, R.L. Factor Analysis, 2nd ed.; Lawrence Erlbaum: Hillsdale, NJ, USA, 1983.

89. Kline, P. Psychometrics and Psychology; Academic Press: London, UK, 1979.

90. Gorsuch, R.L. Factor Analysis; W.B Saunders Co.: Philadelphia, PA, USA, 1974.

91. Data Terbuka. Bilangan Guru Mengikut Sekolah dan PPD di Selangor (Number of Teachers by Schools and District Education Offices in Selangor). Available online: https://www.data.gov.my/data/ms_MY/dataset/bilangan-guru-selangor/resource/b2 ed2175-36c8-4d33-bac6-3eec8d167ff4 (accessed on 17 September 2020).

92. Krejcie, R.V.; Morgan, D.W. Determining Sample Size for Research Activities. Educ. Psychol. Meas. 1970, 30, 607-610. [CrossRef]

93. Creswell, J.W.; Clark, V.L.P. Designing and Conducting Mixed Methods Research; Sage Publications: Thousand Oaks, CA, USA, 2017.

94. Hair, J.F.; Black, W.C.; Babin, B.J.; Anderson, R.E. Multivariate Data Analysis; Prentice-Hall: Upper Saddle River, NJ, USA, 2010.

95. Kline, R.B. Principles and Practice of Structural Equation Modeling, 2nd ed.; The Guilford Press: New York, NY, USA, 2005.

96. Kaiser, H. A second-generation Little Jiffy. Psychometrika 1970, 35, 401-415. [CrossRef]

97. Kaiser, H. An index of factorial simplicity. Psychometrika 1974, 39, 31-36. [CrossRef]

98. Pallant, J. SPSS Survival Manual: A Step by Step Guide to Data Analysis Using IBM SPSS, 3rd ed.; McGraw Hill: Maidenhead, UK, 2007.

99. Hamzah, M.I.M.; Juraime, F.; Mansor, A.N. Malaysian principals' technology leadership practices and curriculum manage-ment. Creat. Educ. 2016, 7, 922-930. [CrossRef]

100. Kondakci, Y.; Beycioglu, K.; Sincar, M.; Ugurlu, C.T. Readiness of teachers for change in schools. Int. J. Leadersh. Educ. 2017, 20, 176-197. [CrossRef] 